\title{
Meningkatkan Keaktifan Dan Hasil Belajar Peserta Didik Melalui Model Pembelajaran Guided Discovery Learning
}

\author{
Nanang Suherman \\ SMP Al Biruni Cerdas Mulia Bandung, Indonesia \\ suherman.alkhawarizmi@gmail.com
}

\begin{abstract}
Abstrak
Keaktifan peserta didik kelas IX di SMP Al Biruni Cerdas Mulia pada pelajaran Matematika selama pembelajaran daring menunjukan peserta didik kurang aktif baik dalam pembelajaran sinkron maupun asinkron. Selain itu hasil belajar sebagian besar peserta didik masih dibawah KKM yang ditentukan. Sehingga diperlukan suatu model pembelajaran yang berbeda dari sebelumnya. Penelitian ini bertujuan untuk meningkatkan keaktifan dan hasil belajar peserta didik melalui model guided discovery learning. Penelitian ini termasuk jenis penelitian tindakan kelas, yang terdiri atas tiga siklus dimana tiap siklus satu kali pertemuan yang melalui tahap perencanaan, pelaksanaan, pengamatan dan refleksi. Subjek dari penelitian ini adalah 23 siswa kelas IX SMP Al Biruni Cerdas Mulia Bandung. Materi yang digunakan adalah fungsi kuadrat. Instrumen pengambilan data yang digunakan meliputi lembar observasi keaktifan peserta didik, lembar angket keaktifan peserta didik, hasil evaluasi belajar dan dokumentasi. Teknik pengumpulan data yang digunakan adalah tes, angket dan dokumentasi. Teknik analisis data yang digunakan adalah data hasil observasi,angket dan hasil tes. Hasil penelitian menunjukan adanya peningkatan keaktifan dan hasil belajar. Hal ini terlihat berdasarkan observasi keaktifan, pada siklus 1 diperoleh keaktifan peserta didik termasuk kategori sedang sebesar $66 \%$, pada siklus 2 diperoleh keaktifan peserta didik termasuk kategori sedang sebesar $74 \%$ dan pada siklus 3 diperoleh keaktifan peserta didik termasuk kategori tinggi sebesar $82 \%$. Berdasarkan hasil angket keaktifan peserta didik, pada siklus 1 diperoleh keaktifan peserta didik termasuk kategori sedang sebesar $73 \%$, pada siklus 2 diperoleh keaktifan peserta didik termasuk kategori tinggi sebesar $77 \%$ dan pada siklus 3 diperoleh keaktifan peserta didik termasuk kategori tinggi sebesar $82 \%$. Berdasarkan hasil belajar, diperoleh rata-rata hasil belajar peserta didik pada siklus 1 sebesar 60,30 , pada siklus 2 sebesar 67,09 dan pada siklus 3 sebesar 78,64. Sedangkan persentase ketuntasan klasikalnya dipeoleh pada siklus 1 sebesar $39 \%$, pada siklus 2 sebesar $43 \%$ dan pada siklus 3 sebesar $83 \%$. Dari hasil yang diperoleh, dapat diambil simpulan bahwa penerapan model Guided Discovery Learning dapat meningkatkan keaktifan dan hasil belajar peserta didik pada pembelajaran matematika. Berdasarkan hasil penelitian, maka guru disarankan untuk menerapkan model Guided Discovery Learning.
\end{abstract}

Katakunci: keaktifan, hasil belajar, Guided Discovery Learning.

\section{Abstract}

The activeness of $9^{\text {th }}$ grade students in SMP Al Biruni Cerdas Mulia to Mathematics during online classes shows that the students are less active in both synchronous and asynchronous learning. In addition, the learning outcomes of most students are still below the specified KKM therefore we require a different learning model from the prior method. This study aims to intensify the activeness and learning outcomes of students through the guided 
discovery learning model. This research is a classroom action research, which consists of three cycles. Each meeting cycle goes through the planning, implementing, observing and reflecting. The subjects of this study were 23 students of $9^{\text {th }}$ grade students in SMP Al Biruni Cerdas Mulia Bandung. The utilized material is a quadratic function. The instruments used to collect the data were the students' activeness observation sheet, the students' activeness questionnaire, and the results of learning evaluation and documentation. The data collection techniques used were tests, questionnaires and documentation. Moreover, the data analysis techniques used were observation data, questionnaires and test results. The results show that there is an increase in both students' activity and learning outcomes. This could be observed based on the observations of activeness. In cycle 1, it was found that the activeness of students is in the medium category of $66 \%$, in cycle 2 the is in the medium category of $74 \%$, and in cycle 3 is in the high category of $82 \%$. Based on the results of the students' activeness questionnaire, in cycle 1, we obtained that the activeness of students is in the medium category of 73\%, meanwhile in cycle 2 is in the high category of $77 \%$ and in cycle 3 is in the high category by $82 \%$. Based on the learning outcomes, the average of learning outcomes of students in cycle 1 is 60.30, cycle 2 was 67.09 and cycle 3 is 78.64. Meanwhile the percentage of classical completeness obtained in cycle 1 is $39 \%$, in cycle 2 was $43 \%$ and in cycle 3 is $83 \%$. From the results obtained, we conclude that the application of the Guided Discovery Learning model is capable of increasing the activeness and learning outcomes of students in learning mathematics. Based on the research results, this method is able to be applied for teachers and either highly recommended.

Keywords: students' activity, learning outcomes, Guided Discovery Learning

\section{PENDAHULUAN}

Matematika sebagai salah satu pelajaran di sekolah cukup memegang peranan penting dalam membentuk siswa yang berkualitas, karena matematika merupakan suatu sarana berfikir untuk mengkaji segala sesuatu secara logis dan sistematis. Oleh karena itu, perlu adanya peningkatan kualitas pendidikan dibidang matematika. Hal yang perlu diperhatikan agar adanya peningkatan kualitas pendidikan dibidang matematika adalah keaktifan dan hasil belajar peserta didik pada pelajaran matematika di sekolah.

Belajar merupakan wujud tindakan keaktifan siswa. Keaktifan siswa dapat diartikan segala tindakan oleh siswa untuk dapat berinteraksi dengan lingkungan sekitar. Dalam hal ini siswa dituntut untuk lebih aktif belajar seperti membaca, menulis, dan berdiskusi, bukan hanya sekedar menerima informasi dari guru.

Setiap proses pembelajaran selalu menghasilkan hasil belajar. Menurut Suprijono, (2016:5) Hasil 
belajar merupakan perbuatan, nilai, pengertian, sikap, apresiasi, dan keterampilan. Sedangkan menurut Sudjana (2014:22), Hasil belajar adalah kemampuan siswa setelah menerima pengalaman belajar.

Pembelajaran matematika di SMP Al Biruni Cerdas Mulia selama ini masih kurang bervariasi dan kreatif. Metode yang sering digunakan dalam pembelajaran matematika adalah ceramah dan tanya jawab. Guru hanya menjelaskan suatu konsep materi berikut contoh soal kemudian siswa diberi latihan. Penggunaan model pembelajaran secara konvensional ini membuat siswa menjadi pasif, sehingga mengakibatkan kurangnya keaktifan dan rendahnya hasil belajar matematika. Hal ini terlihat dari pencapaian hasil belajar sebagian siswa yang masih belum memenuhi nilai KKM yang telah ditentukan yaitu 75. Berdasarkan pembelajaran daring yang telah dilaksanakan, tingkat keaktifan peserta didik pada pembelajaran matematika masih rendah.

Hal-hal seperti inilah yang menarik minat penulis untuk mengadakan penelitian di SMP Al Biruni Cerdas Mulia. Penelitian yang dimaksud berupa Penelitian Tindakan Kelas untuk memperbaiki pembelajaran. Menurut Wijaya Kusuma (2009:9) penelitian tindakan kelas adalah penelitian tindakan yang dilakukan oleh guru di dalam kelas. Menurut O'Brien sebagaimana dikutip oleh Endang Mulyatiningsih (2011:60) penelitian tindakan kelas adalah penelitian yang dilakukan ketika sekelompok orang (siswa) diidentifikasi permasalahannya, kemudian peneliti (guru) menetapkan suatu tindakan untuk mengatasinya.

$$
\text { Menurut Hopkins }
$$
penelitian tindakan kelas diawali dengan perencanaan tindakan (Planning), penerapan tindakan (action), mengobservasi dan mengevaluasi proses dan hasil tindakan (Observation and evaluation). Sedangkan prosedur kerja dalam penelitian tindakan kelas terdiri atas empat komponen, yaitu perencanaan (planning), pelaksanaan (acting), pengamatan (observing), dan refleksi (reflecting), dan seterusnya sampai perbaikan atau peningkatan yang diharapkan tercapai (kriteria keberhasilan).

Penulis memandang dalam pembelajaran matematika di sekolah diperlukan suatu model pembelajaran yang lebih bervariasi lagi dari pada sebelumnya. Salah satu model pembelajaran yang cukup bervariasi 
dan dapat melibatkan peran aktif peserta didik dalam kegiatan belajar mengajar adalah model pembelajaran Guided Discovery Learning. Melalui model pembelajaran ini siswa dibimbing untuk dapat mengemukakan pemikirannya, saling bertukar pendapat, saling bekerja sama dalam kelompoknya jika mengalami kesulitan dalam memahami materi. Hal ini dapat meningkatkan keaktifan siswa untuk mengkaji dan menguasai materi pelajaran matematika. Dengan pemilihan model ini, diharapkan pembelajaran yang terjadi dapat lebih bermakna dan memberi kesan yang kuat kepada siswa dalam belajar matematika.

Model pembelajaran penemuan (Discovery Learning) dari Bruner adalah salah satu model pembelajaran instruksional yang sangat berpengaruh dalam dunia pendidikan. Berusaha sendiri untuk mencari pemecahan masalah serta pengetahuan yang menyertainya akan menghasilkan pengetahuan yang benar-benar bermakna. Model pembelajaran ini terbukti berhasil meningkatkan pemahaman konsep peserta didik (Suryanti, 2015).

Model pembelajaran penemuan terbimbing adalah model pembelajaran dimana siswa tidak disajikan pelajaran dalam bentuk finalnya, tetapi siswa harus menyampaikan ide-ide mereka sebelum topik-topik tersebut mereka pelajari, siswa menyelidiki sebuah gejala atau fenomena yang mereka anggap ganjil, siswa menjelaskan fakta-fakta dan membandingkannya secara saintifik, selain itu siswa menanyakan mengenai sebuah situasi yang mendukung pembelajaran tersebut.

Adapun langkah-langkah model Guided Discovery Learning yang dipakai dalam penelitian ini meliputi:

Stimulation

(stimulasi/pemberian rangsangan), (2) Problem statement (identifikasi masalah), (3) Data collection (pengumpulan data). (4) Data processing (pengolahan data), (5) Verification (pembuktian) dan (6) Generalization (menarik kesimpulan).

\section{METODE}

Penelitian yang telah dilaksanakan merupakan Penelitian Tindakan Kelas (PTK) yang dilaksanakan di kelas IX SMP Al Biruni Cerdas Mulia Bandung dengan jumlah peserta didik sebanyak 36 orang. Subjek penelitian merupakan peneliti sendiri selaku guru mata pelajaran Matematika, sedangkan objek dari penelitian ini adalah keaktifan dan hasil belajar peserta 
didik. Tujuan dari penelitian ini yaitu:

(1) Mengetahui keaktifan peserta didik melalui model pembelajaran Guided Discovery Learning pada pokok bahasan fungsi kuadrat kelas IX B SMP Al Biruni Cerdas Mulia. (2) Mengetahui hasil belajar peserta didik melalui model pembelajaran Guided Discovery Learning pada pokok bahasan fungsi kuadrat kelas IX B SMP Al Biruni Cerdas Mulia.

Penelitian ini dilaksanakan selama 3 siklus dengan 3 kali pertemuan. Masing-masing pertemuan dilaksanakan dalam 2 jam pelajaran. Tahapan pada setiap siklus terdiri atas tahap rencana tindakan, pelaksanaan tindakan, pengamatan dan evaluasi, analisis dan refleksi. Seluruh kegiatan penelitian pada setiap siklus diawali dengan merencanakan kegiatan yang akan diimplementasikan dalam tahap pelaksanaan tindakan. Tahapan perencanaan berupa persiapan perangkat pembelajaran dan perencanaan tindakan. Pada tahapan pelaksanaan tindakan, peneliti melaksanakan tindakan sesuai dengan perangkat yang telah dibuat dan melakukan observasi untuk mendapatkan data dan informasi. Data dan informasi yang diperoleh akan dianalisis sebagai bahan refleksi. Pada kegiatan refleksi memberikan gambaran data dan informasi yang diperoleh untuk dijadikan umpan balik dalam rangka perbaikan tindakan untuk siklus berikutnya. Instrumen yang digunakan dalam penelitian ini antara lain (1) lembar observasi keaktifan peserta didik untuk mengetahui sejauhmana keaktifan peserta didik, (2) angket respon keaktifan peserta didik untuk mengetahui penilaian diri terhadap keaktifan peserta didik, (3) tes evaluasi hasil belajar peserta didik untuk mengetahui hasil belajar peserta didik dan (3) dokumentasi berupa video rekaman proses pembelajaran daring yang digunakan untuk membantu menggambarkan apa yang terjadi selama proses pembelajaran.

Metode pengumpulan data yang digunakan adalah metode observasi, angket dan tes. Teknik analisis data yang digunakan adalah analisis data observasi keaktifan, angket respon peserta didik, dan hasil belajar peserta didik. Data yang diperoleh dianalisis secara kuantitatif dengan pengujian statistika deskriptif untuk menggambarkan hasil yang diperoleh. Adapun kriteria keaktifan peserta didik pada pembelajaan menurut (Arikunto, 2007:18) tersaji pada Tabel 1 berikut. 
Tabel 1. Kriteria Keaktifan Peserta Didik dalam Pemebelajaran

\begin{tabular}{cc}
\hline Capaian & Kriteria \\
\hline $75 \%-100 \%$ & Tinggi \\
\hline $51 \%-74 \%$ & Sedang \\
\hline $25 \%-50 \%$ & Rendah \\
\hline $0 \%-24 \%$ & Sangat Rendah
\end{tabular}

Sedangkan kriteri yang digunakan untuk hasil belajar, peserta didik dinyatakan tuntas jika memperoleh nilai $\geq 75$.

\section{HASIL DAN PEMBAHASAN}

Berdasarkan hasil penelitian menggunakan model Guided Discovery Learning diperoleh data yang menggambarkan peningkatan keaktifan peserta didik ditunjukkan pada Tabel 2.

Tabel 2. Hasil Observasi dan Angket keaktifan Peserta Didik

\begin{tabular}{|c|c|c|c|c|}
\hline \multirow[t]{2}{*}{ No } & \multirow{2}{*}{$\begin{array}{c}\text { Instrumen } \\
\text { Keaktifan } \\
\text { Peserta } \\
\text { Didik }\end{array}$} & \multicolumn{3}{|c|}{ Persentase Keaktifan } \\
\hline & & $\begin{array}{c}\text { Siklus } \\
\text { I }\end{array}$ & $\begin{array}{c}\text { Siklus } \\
\text { II }\end{array}$ & $\begin{array}{c}\text { Siklus } \\
\text { III }\end{array}$ \\
\hline 1. & $\begin{array}{l}\text { Lembar } \\
\text { observasi } \\
\text { keaktifan }\end{array}$ & 66 & 74 & 82 \\
\hline 2. & $\begin{array}{l}\text { Angket } \\
\text { keaktifan }\end{array}$ & 73 & 77 & 82 \\
\hline
\end{tabular}

Berdasarkan tabel diatas, dapat dideskripsikan bahwa keaktifan peserta didik pada Siklus I, Siklus II dan Siklus III mengalami peningkatan. Tergambar dalam gambar berikut.

\section{Keaktifan Peserta Didik}

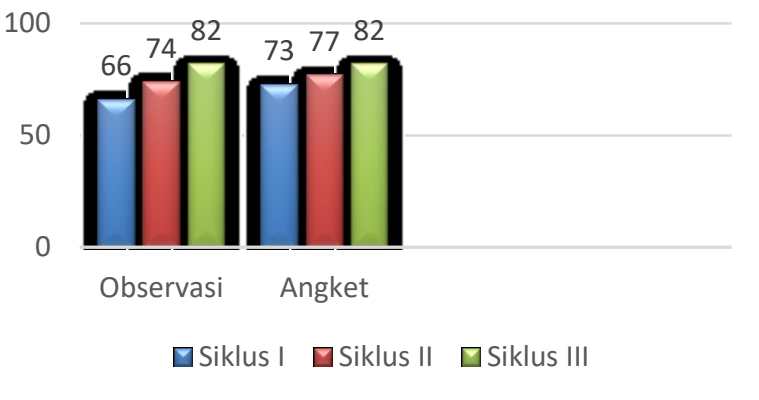

Gambar 1. Peningkatan Keaktifan Peserta Didik

Pada siklus I diperoleh hasil lembar observasi keaktifan sebesar $66 \%$ termasuk kategori sedang dan hasil angket keaktifan sebesar 73\% termasuk kategori sedang. Keaktifan peserta didik baik dari hasil lembar observasi maupun angket keaktifan belum memenuhi kriteria indikator keberhasilan yang ditentukan dikarenakan belum mencapai $\geq 75 \%$ dengan kriteria tinggi. Hal ini dikarenakan peserta didik belum terbiasa dengan model pembelajaran yang diterapkan. Pada siklus II keaktifan peserta didik mengalami kenaikan dengan diperoleh hasil lembar observasi keaktifan sebesar 74\% termasuk kategori sedang dan hasil angket keaktifan sebesar $77 \%$ termasuk kategori tinggi. Keaktifan peserta didik berdasarkan hasil lembar observasi belum memenuhi kriteria indikator keberhasilan yang ditentukan dikarenakan belum mencapai $\geq 75 \%$ dengan kriteria tinggi. Sedangkan untuk hasil angket keaktifan sudah mencapai indikator keberhasilan yang ditentukan. Hal ini 
dikarenakan peserta didik mulai terbiasa untuk berdiskusi aktif dalam kelompok dan melakukan presentasi kelompok. Pada siklus III keaktifan peserta didik mengalami kenaikan dengan diperoleh hasil lembar observasi keaktifan sebesar $82 \%$ termasuk kategori tinggi dan hasil angket keaktifan sebesar $82 \%$ termasuk kategori tinggi. Keaktifan peserta didik baik dari hasil lembar observasi maupun angket keaktifan sudah memenuhi kriteria indikator keberhasilan yang ditentukan dikarenakan sudah mencapai $\geq 75 \%$ dengan kriteria tinggi. Hal ini dikarenakan peserta didik sudah terbiasa dengan pembelajaran yang menuntut mereka untuk aktif berdiskusi dan melaksanakan presentasi. Aktifitas keaktifan peserta didik jelas terlihat ketika diskusi kelompok kecil dan presentasi kelompok. Pada mulanya peserta didik merasa kesulitan untuk berdiskusi melalui grup WA karena kebiasaan di sekolah biaanya diskusi langsung. Lambat laun peserta didik mulai terbiasa dan terlihat aktif dalam kegiatan diskusi. Pada kegiatan presentasi melalui zoom meeting, perkembangan keberanian peserta didik untuk presentasi mengalami peningkatan dan saling menanggapi antar kelompok.

Berdasarkan hasil evaluasi belajar peserta didik yang dikerjakan setiap akhir pembelajaran, diperoleh data yang menggambarkan peningkatan hasil belajar peserta didik ditunjukkan pada Tabel 3.

Tabel 3. Hasil Belajar Peserta Didik

\begin{tabular}{|l|l|c|c|c|}
\hline No & \multirow{2}{*}{$\begin{array}{c}\text { Aspek Hasil } \\
\text { Belajar }\end{array}$} & $\begin{array}{c}|c| \\
\text { Riklus } \\
\text { I }\end{array}$ & $\begin{array}{c}\text { Siklus } \\
\text { II }\end{array}$ & $\begin{array}{c}\text { Siklus } \\
\text { III }\end{array}$ \\
\hline 1. & $\begin{array}{l}\text { Rata-rata } \\
\text { hasil belajar }\end{array}$ & 60,30 & 67,09 & 78,64 \\
\hline 2. & $\begin{array}{l}\text { Ketuntasan } \\
\text { Klasikal }\end{array}$ & 39 & 43 & 83 \\
\hline
\end{tabular}

Berdasarkan tabel diatas, dapat dideskripsikan bahwa hasil belajar peserta didik pada Siklus I, Siklus II dan Siklus III mengalami peningkatan. Tergambar dalam gambar berikut.

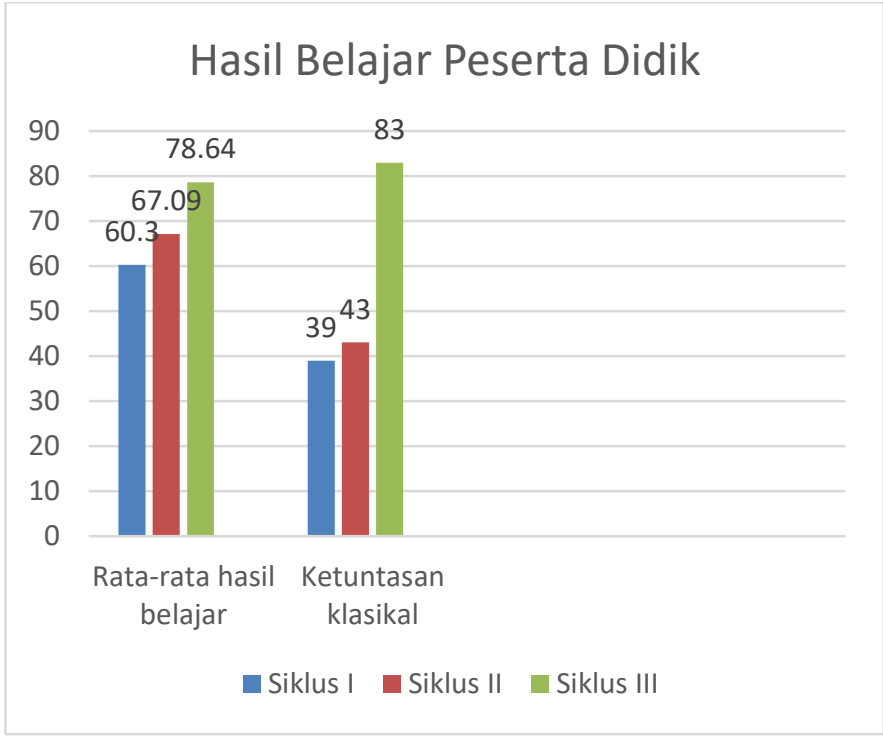

Gambar 2. Peningkatan Hasil Belajar Peserta Didik

Pada siklus I diperoleh rata-rata hasil belajar peserta didik sebesar 60,30 dan ketuntasan klasikalnya sebesar 39\%. Ratarata hasil belajar peserta didik belum memenuhi kriteria indikator pencapaian yang ditentukan dikarenakan belum 
mencapai $\geq 75$. Untuk ketuntasan klasikal juga belum memenuhi kriteria indikator pencapaian yang ditentukan dikarenakan belum mencapai $\geq 80 \%$. Hal ini dikarenakan peserta didik belum terbiasa dengan model pembelajaran yang diterapkan dan masih belum bisa mengikuti pembelajaran dengan baik. Pada siklus II hasil belajar peserta didik mengalami kenaikan dengan diperoleh rata-rata hasil belajar peserta didik sebesar 67,09 dan ketuntasan klasikalnya sebesar 43\%. Rata-rata hasil belajar peserta didik belum memenuhi kriteria indikator pencapaian yang ditentukan dikarenakan belum mencapai $\geq 75$. Untuk ketuntasan klasikal juga belum memenuhi kriteria indikator pencapaian yang ditentukan dikarenakan belum mencapai $\geq 80 \%$. Hasil belajar dari siklus I ke siklus II sebetulnya ada peningkatan walaupun memang belum memenuhi kriteria yang ditentukan. Secara perlahan peserta didik mulai dapat mengikuti pembelajaran. Pada siklus III hasil belajar peserta didik mengalami kenaikan dengan diperoleh rata-rata hasil belajar peserta didik sebesar 78,64 dan ketuntasan klasikalnya sebesar 83\%. Rata-rata hasil belajar peserta didik sudah memenuhi kriteria indikator pencapaian yang ditentukan dikarenakan sudah mencapai $\geq 75$. Untuk ketuntasan klasikal juga sudah memenuhi kriteria indikator pencapaian yang ditentukan dikarenakan belum mencapai $\geq 80 \%$. Hal ini dikarenakan peserta didik sudah terbiasa dengan model pembelajaran yang diterapkan dan mampu mengikuti pembelajaran dengan baik.

Berdasarkan hasil lembar observasi keaktifan, angket keaktifan dan hasil belajar peserta didik pada siklus III, hasil penelitian sudah mencapai indikator keberhasilan. Hal tersebut membuktikan bahwa penerapan model Discovery Guided Learning dapat meningkatkan keaktifan dan hasil belajar peserta didik di kelas IX SMP Al Biruni Cerdas Mulia Bandung. Dengan demikian tujuan penelitian dan indikator keberhasilan telah tercapai, rumusan masalah telah terpecahkan, dan hipotesis penelitian telah terbukti.

\section{PENUTUP}

\section{Simpulan}

Simpulan yang diperoleh berdasarkan penelitian yang telah dilaksanakan (1) Penerapan model pembelajaran Guided Discovery Learning dapat meningkatkan keaktifan belajar peserta didik pada materi fungsi kuadrat di kelas IX B SMP Al Biruni Cerdas Mulia. (2) Penerapan model pembelajaran Guided Discovery Learning dapat meningkatkan hasil belajar peserta didik pada materi fungsi kuadrat di 
kelas IX B SMP Al Biruni Cerdas Mulia

\section{Saran}

Berdasarkan hasil penelitian yang dilakukan, peneliti berharap bagi guru Matematika khususnya, dapat menerapkan model pembelajaran Guided Discovery Learning dalam rangka meningkatkan keaktifan peserta didik dalam mempelajari materi, yang akan berdampak pada peningkatan hasil belajar peserta didik. Kemudian bagi peneliti lain, dapat mengadakan penelitian lebih lanjut penerapan model pembelajaran Guided Discovery Learning dengan tema yang lain dalam pembelajaran.

\section{Ucapan Terima Kasih}

Peneliti mengucapkan terimakasih kepada Ibu Maria Susan, S.E, M.M. selaku Kepala SMP Al Biruni Cerdas Mulia Bandung, Ibu Sri Suryanti, M.Si. selaku dosen pembimbing, Ibu Dra. Masfufah selaku guru pamong dan teman-teman mahasiswa PPG daljab angkatan 2 Universitas Muhammadiyah Gresik yang telah berkonstribusi dalam penelitian ini.

\section{Daftar Pustaka}

Amri, Sofan. (2015). Implementasi Pembelajaran Aktif dalam
Kurikulum 2013. Jakarta : Prestasi Pustaka Raya.

Aunurrahman. 2009. Belajar dan Pembelajaran. Bandung: Alfabeta. Huda, Miftahul. (2015). Model-Model Pengajaran dan Pembelajaran .

Yogyakarta : Pustaka Pelajar.

Khiriyah, Afifatul. 2015. Peningkatan Hasil Belajar dan Keaktifan Siswa pada Mata Pelajaran Keterampilan Komputer dan Pengelolaan Informasi (KKPI) Melalui Model Pembelajaran Problem Based Learning (PBL) Kelas XI TKJ di SMK Negeri Sine (Skripsi). Jogjakarta: Universitas Negeri Yogyakarta.

Ningrum, Epon. (2014). Penelitian Tindakan Kelas. Yogyakarta : Penerbit Ombak.

Purwanto, Edy. (2014). Evaluasi Proses dan Hasil Dalam Pembelajaran. Yogyakarta : Penerbit Ombak.

Ratnawulan, Elis \& H. A. Rusdiana. (2014). Evaluasi Pembelajaran. Bandung : Pustaka Setia.

Rotamya, Abdai Riska. 2017. Pengaruh Model Pembelajaran Penemuan Terbimbing (Guided Discovery) Terhadap Hasil Belajar Pada Materi Relasi Fungsi Siswa Kelas X Ma Swasta 
Di Tulungagung (Skripsi).Tulungagung: Institut Agama Islam Negeri (IAIN) Tulungagung

Sudjana, Nana. (2014). Penilaian Hasil dan Proses Belajar Mengajar. Bandung : PT Remaja Rosdakarya. Warsono \& Hariyanto. (2013). Pembelajaran Aktif Teori dan Asesmen. Bandung : PT Remaja Rosdakarya.

Sanjaya, Wina. 2016. Penelitian Tindakan Kelas. Jakarta: Kencana Prenada Media.

Suryanti, S. (2015). Peningkatan kepercayaan diri dan kemampuan pemecahan masalah mahasiswa pada mata kuliah matematika diskrit melalui discovery learning. DIDAKTIKA: Jurnal Pemikiran Pendidikan, 22(1), 64-73. https://doi.org/doi:10.1234/didakti ka.v22i1.148

Wulandari, Tutik. 2015. Peningkaran Keaktifan dan Hasil Belajar Matematika Melalui Model Pembelajaran Problem Based Learning (PTK pada Siswa Kelas VIIIG Semester Genap SMP Negeri
1 Kartasura Tahun Pelajaran 2014/2015) (Skripsi). Surakarta: Universitas Muhammadiyah Surakarta.

Zainal Aqib. (2009). Penelitian Tindakan Kelas Untuk Guru. Bandung: Yrama Widya. 
